\title{
Pregnancy Induced Hypertension and Associated Factors among Pregnant Women
}

\author{
Sarker Shamima Ahmed ${ }^{1}$, Nazma Sultana ${ }^{2 *}$, Most Luthy Begum ${ }^{3}$, Lobaba Sultana Lima ${ }^{4}$, Md Firoz Abedin ${ }^{5}$ and \\ Md Kausar Hosen 6 \\ ${ }^{1}$ Department of Community Medicine, Tairunnessa Memorial Medical College \& Hospital, Bangladesh \\ ${ }^{2}$ Ad-din Medical College \& Hospital, Bangladesh
}

${ }^{3}$ Northern University Bangladesh, Bangladesh

${ }^{4}$ American International University, Bangladesh

${ }^{5}$ Department of Zoology, Jogonnath University, Bangladesh

${ }^{6}$ Lalmonirhat Sadar Hospital, Bangladesh

Submission: March 09, 2017; Published: March 30, 2017

*Corresponding author: Nazma Sultana, Medical Officer, Ad-din Medical College \& Hospital, Bangladesh, Email: gpabd17@gmail.com

\begin{abstract}
Pregnancy induced hypertension is a burning issue in terms of maternal mortality and morbidity not only in Bangladesh but also worldwide. Actually it is risk factor for both mother and child. This cross sectional hospital based study was conducted to assess prevalence of pregnancy induced hypertension and its determinants among pregnant women attending teaching hospital in third trimester. Non probability purposive sampling was used to collect sample. Structured questionnaire was used to collect data. Face to face interview was taken as well as medical record was checked. Average age of the respondent's $26.03 \pm 5.77$ years. More than half of the respondents completed SSC level education. Average income of the respondent's was 33100.00 \pm 76135.29 BDT. Three-fourth of the respondents had family history of hypertension. More than half of the respondents (64\%) suffered from moderate anemia. Average ANC visit was 4.43 \pm 1.58 . Multipara, primipara and nullipara were $63 \%, 33 \%$ and $4 \%$ respectively. Underweight, normal, overweight and obese were $4 \%, 28.50 \%, 26.50 \%$ and $41 \%$. The prevalence of pregnancy induced hypertension was $7.5 \%$. Statistical significant association was found between pregnancy induced hypertension and socioeconomic status. Further large scale depth study can be conducted to get more precise result.
\end{abstract}

Keywords: Pregnancy induced hypertension; Associated factors

\section{Introduction}

Pregnancy is a physiological phenomenon for most women. However, some develop problems during its evolution, putting both the mothers and the conceptus health at sake [1]. Gestational hypertension is the most common cause of hypertension in pregnant women. Gestational hypertension is a clinical diagnosis defined by the new onset of hypertension (systolic blood pressure $\geq 140 \mathrm{mmHg}$ and/or diastolic blood pressure $\geq 90 \mathrm{mmHg}$ ) at $\geq 20$ weeks of gestation in the absence of proteinuria or new signs of end-organ dysfunction [2]. The blood pressure readings should be documented on at least two occasions at least four hours apart. Gestational hypertension is severe when systolic blood pressure is $\geq 160 \mathrm{mmHg}$ and/or diastolic blood pressure is $\geq 110$ mmHg on two consecutive blood pressure measurements at least four hours apart [3-5]. Gestational hypertension is one of the maternal diseases that causes the most detrimental effects to the maternal, fetal, and neonatal organisms. This disease is responsible for high maternal and perinatal morbidity and mortality rates, and is one of the main public health problems [6,7]. According to the Health Ministry, hypertension during pregnancy, depending on the severity level, is considered a risk factor, which, associated with individual characteristics, unfavorable socioeconomic conditions, certain obstetric histories and clinical problems could trigger harms to the maternal-fetal binomial [8]. The hypertensive syndromes of pregnancy are the leading cause of maternal and fetal morbidity and mortality in the developed world $[9,10]$, occurring in around $8 \%$ of pregnancies. Hypertensive syndromes are also a cause of perinatal morbidity and mortality, mainly from intrauterine growth restriction due to utero-placental insufficiency and complications related to prematurity [11]. Even mild hypertension is associated with greater risk for prematurity and newborns who are small for gestational age [12]. Despite the severity of disease of both 
preeclampsia and gestational hypertension, differences in risk factors between severe preeclampsia and gestational hypertension may increase controversies over expectant versus aggressive treatment, and there is insufficient literature on Asian women with preeclampsia and gestational hypertension regarding the issue of maternal complications [13]. Recent studies have indicated higher risk of PIH among women with family history of hypertension, previous history of pregnancy induced hypertension, pre-exciting diabetes, gestational diabetes mellitus, maternal age $\geq 40$ years, multiple pregnancies, nulliparity, and pre-pregnancy obesity [14]. Some prior studies have suggested that higher pre-pregnancy body mass index is associated with increased risk of gestational hypertension and pre-eclampsia [15]. Gestational hypertension is still a little-understood entity. Hypertensive disorders in pregnancy are common and their incidence appears to be increasing. Gestational hypertension is an abnormality causing striking maternal, fetal and neonatal mortality and morbidity both in developed and developing countries. Gestational hypertension is found in 5-10\% of pregnancies in the world. Increase in caesarean section, abruption of premature placenta, preterm delivery, low birth weight, stillbirth, acute renal failure, and intravascular coagulation were more frequently observed in women who developed hypertensive disorders of pregnancy. The crude prevalence of systolic and diastolic hypertension in pregnancy in rural area of Bangladesh was $6.8 \%$ and $5.4 \%$, respectively. It is proved that gestational hypertension and low birth weight is well linked. So prevalence of gestational hypertension among pregnant women in Bangladesh context specially urban based study in a teaching hospital is an urgent need.

\section{Materials and Methods}

This cross sectional study was conducted at conveniently selected at Ad-din Medical College \& Hospital, Keraniganj, Dhaka. This area was purposively selected to get adequate sample. Study was run for three months from $1^{\text {st }}$ September, 2016 to $30^{\text {th }}$ November, 2016. Non probability convenient sampling method was used on the basis of inclusion and exclusion criteria. The study was mainly based on primary data. It consists of both data gathered by structured and semi structured questionnaires and in depth interviews with Bangladeshi women. The socioeconomic scenarios of the respondents were obtained. Blood pressure was measured by investigator herself. Medical records were also verified. The respondents were selected consecutively who meet the inclusion and exclusion criteria. Data were collected by interviewer administered questionnaires. Questionnaires was comprised of several topics, including sociodemographic background (age, educational status, occupation, monthly income, etc.), blood pressure status and BMI. After data collection, data were sorted and scrutinized by me and then data were analyzed by SPSS version 20.0 program. The open ended questions were grouped and categorized. Data were analyzed by descriptive statistics and inferential statistics.

\section{Results}

Table 1: Age group distribution of the respondents $(n=200)$.

\begin{tabular}{|c|c|c|}
\hline Age in years & Frequency & Percentage \\
\hline $17-23$ & 66 & 33 \\
\hline $24-30$ & 113 & 56.5 \\
\hline $31-37$ & 8 & 4 \\
\hline $38-43$ & 13 & 6.5 \\
\hline Mean \pm SD & \multicolumn{2}{|c|}{$26.03 \pm 5.77$} \\
\hline
\end{tabular}

Table shows that mean age of the respondent's $26.03 \pm 5.77$ years. More than half of the respondents represented 24-30 years age group followed by $17-23$ years $33 \%, 31-37$ years $4 \%$ and $38-43$ years $6.5 \%$.
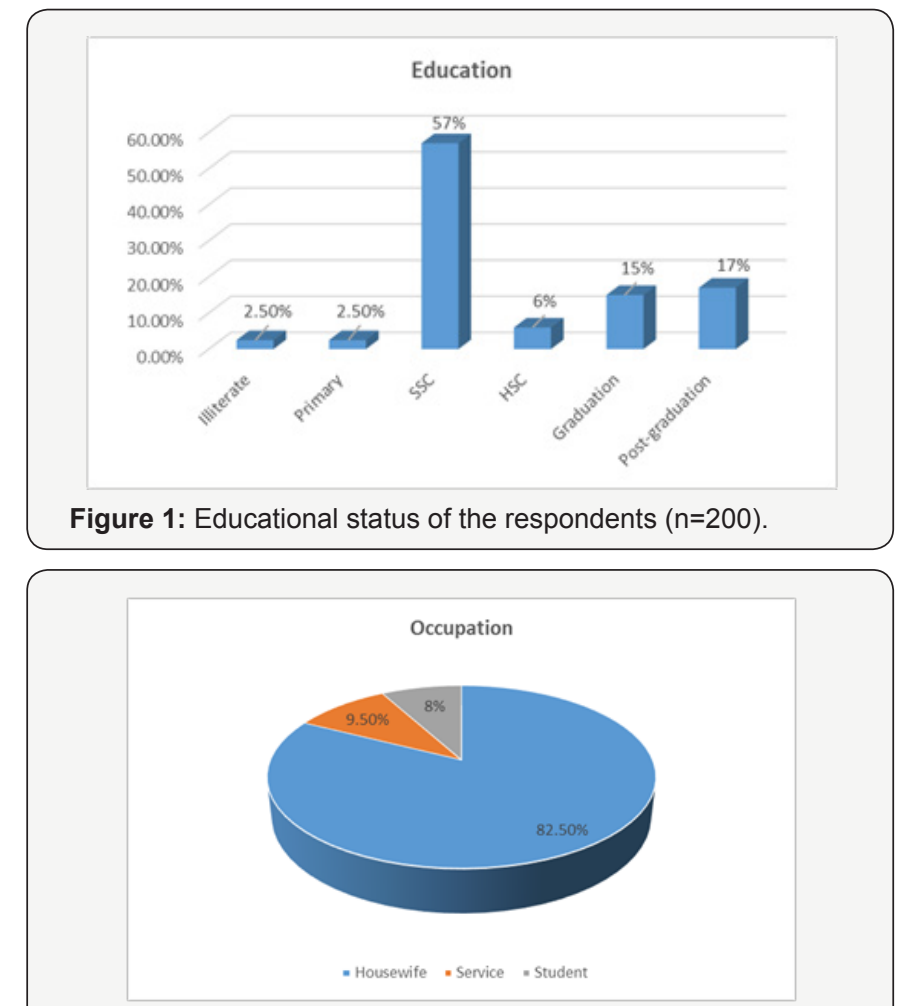

Figure 2: Occupational status of the respondents $(n=200)$.

Table 2: Monthly income of the respondents $(n=200)$.

\begin{tabular}{|c|c|c|}
\hline Monthly income & Frequency & Percentage \\
\hline $5000-19999$ & 90 & 45 \\
\hline $20000-34999$ & 59 & 29.5 \\
\hline $35000-49999$ & 30 & 15 \\
\hline $50000-64999$ & 16 & 8 \\
\hline$\geq 65000$ & 5 & 2.5 \\
\hline \multicolumn{2}{|c|}{ Mean \pm SD } & \multicolumn{2}{|c|}{$33100.00 \pm 76135.29$} \\
\hline Table shows that average income of the respondent's was
\end{tabular}

$33100.00 \pm 76135.29$ BDT. About $45 \%, 29.5 \%, 15 \%, 8 \%$ and $2.5 \%$ respondents had monthly income 5000-19999 BDT, 20000-34999 BDT, 35000-49999 BDT, 50000-64999 BDT and $\geq 65000$ BDT.

Table 1 shows that mean age of the respondent's $26.03 \pm 5.77$ years. More than half of the respondents represented 24-30 years age group followed by $17-23$ years $33 \%, 31-37$ years $4 \%$ and 38 - 
43 years $6.5 \%$. More than half of the respondents completed SSC level education followed by post-graduation $17 \%$, graduation $15 \%$, HSC $6 \%$, primary $2.50 \%$ and illiterate $2.50 \%$ (Figure 1 ). Housewife, service and student were $82.50 \%, 9.50 \%$ and $8 \%$ respectively (Figure 2). Table 2 shows that average income of the respondent's was 33100.00 \pm 76135.29 BDT. About 45\%, 29.5\%, $15 \%, 8 \%$ and $2.5 \%$ respondents had monthly income 5000 19999 BDT, 20000-34999 BDT, 35000-49999 BDT, 50000-64999 BDT and $\geq 65000$ BDT. Three-fourth of the respondents had family history of hypertension whereas one-fourth had no family history of hypertension (Figure 3). Almost 98\% respondents had no previous history of pregnancy induced hypertension whereas $2 \%$ had previous history of pregnancy induced hypertension (Figure 4). Six percent pregnant women had history of both pregnancy induced hypertension and gestational diabetes (Figure 5). This doughnut shows $98 \%$ had no history of preeclampsia (Figure 6). More than half of the respondents (64\%) suffered from moderate anemia followed by mild anemia $32 \%$ and severe anemia 4\% (Figure 7). Table 3 shows Average ANC visit was $4.43 \pm 1.58$. Most of the respondents $(72 \%)$ visited ANC $>4$ times. Table 4 shows Prevalence of pregnancy induced hypertension was $7.5 \%$. Statistical significant association was found between pregnancy induced hypertension and age group $(p=0.006<0.05)$ (Table 5). Table 6 shows Statistical significant association was found between pregnancy induced hypertension and education $(\mathrm{p}=0.001<0.5)$. Table 7 shows Statistical significant association was found between pregnancy induced hypertension and occupation $(\mathrm{p}=0.021<0.05)$.

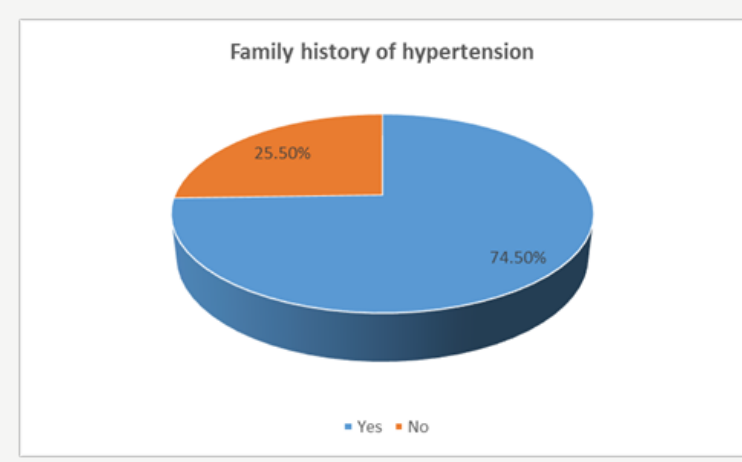

Figure 3: Family history of hypertension $(n=200)$.

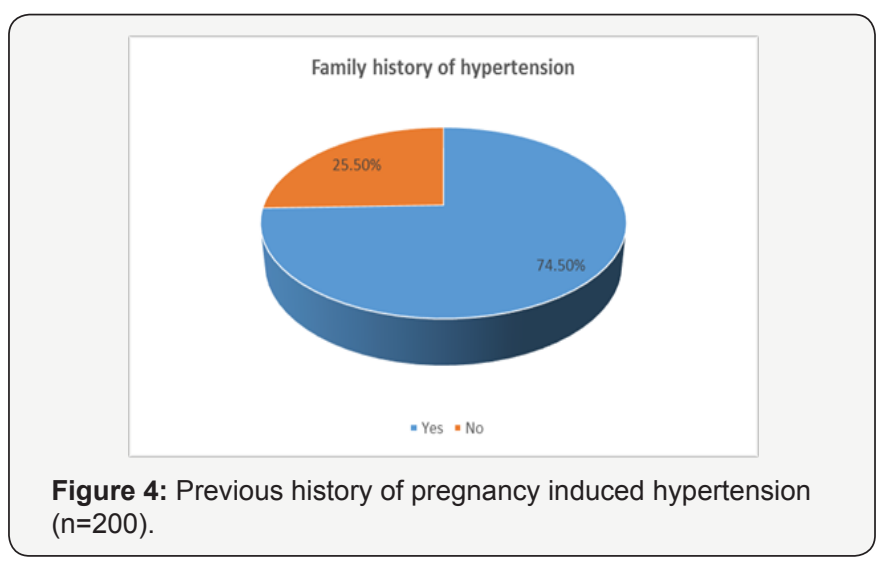

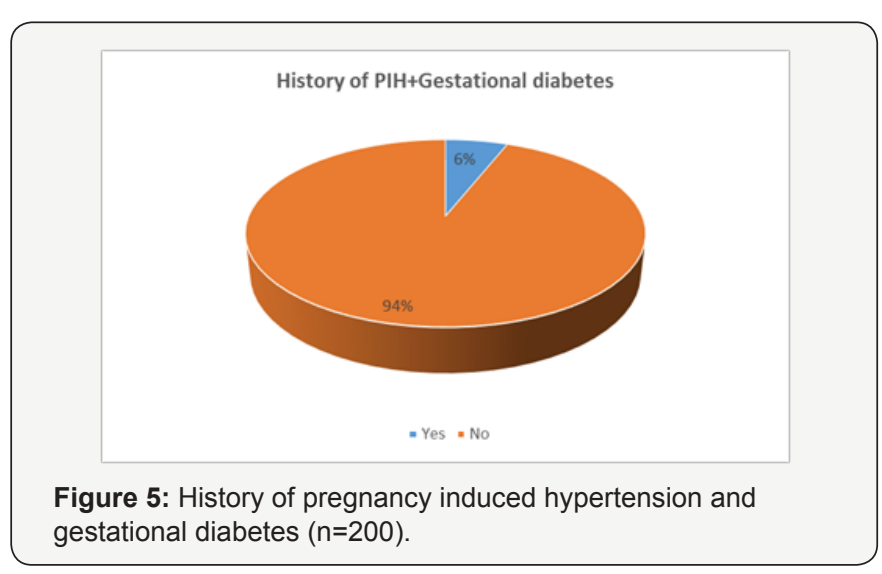
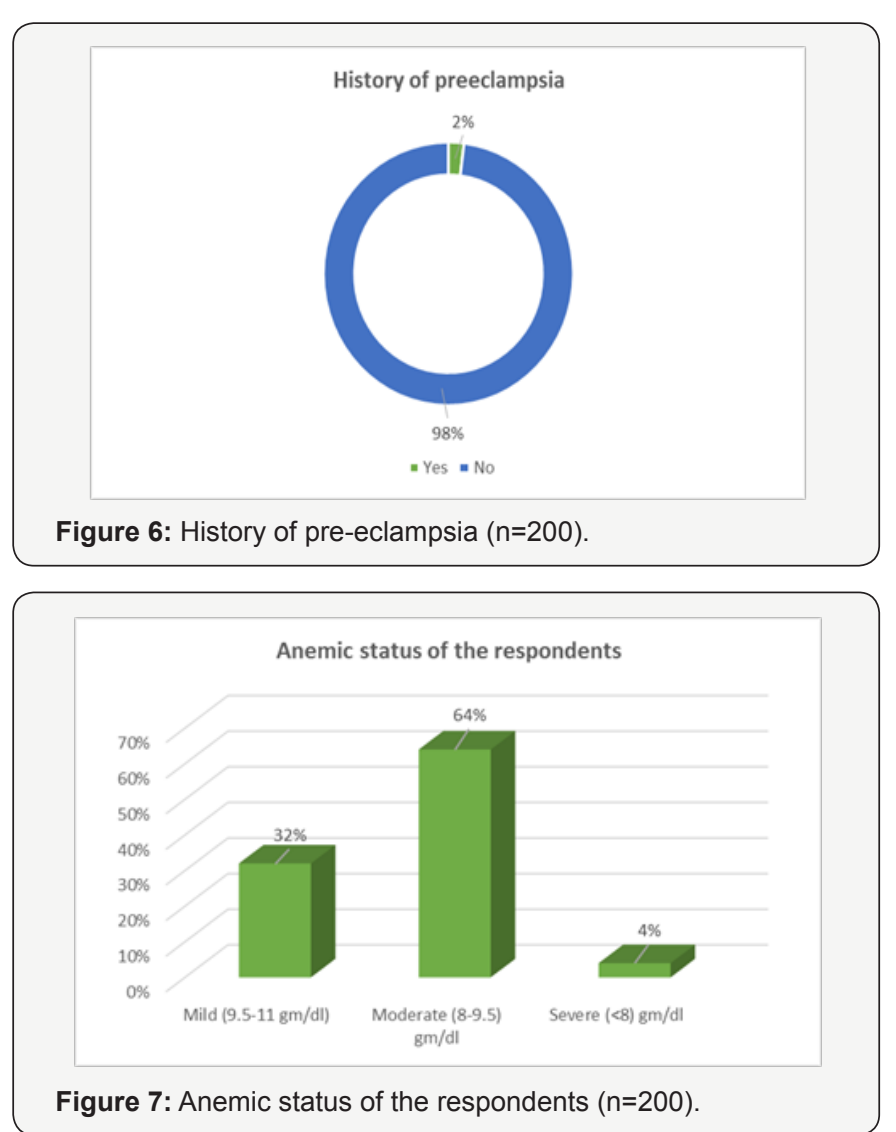

Table 3: Number of ANC visit of the respondents $(n=200)$.

\begin{tabular}{|c|c|c|}
\hline ANC Visit & Frequency & Percentage \\
\hline$\leq 4$ & 56 & 28 \\
\hline$>4$ & 144 & 72 \\
\hline Mean \pm SD & \multicolumn{2}{|c|}{$4.43 \pm 1.58$} \\
\hline
\end{tabular}

Average ANC visit was $4.43 \pm 1.58$. Most of the respondents $(72 \%)$ visited $A N C>4$ times.

Table 4: Prevalence of pregnancy induced hypertension $(n=200)$.

\begin{tabular}{|c|c|c|}
\hline PIH & Frequency & Percentage \\
\hline Yes & 15 & 7.5 \\
\hline No & 185 & 92.5 \\
\hline
\end{tabular}

Prevalence of pregnancy induced hypertension was $7.5 \%$. 
Table 5: Association between pregnancy induced hypertension and age group.

\begin{tabular}{|c|c|c|c|c|c|}
\hline \multirow{3}{*}{ Variables } & \multicolumn{2}{|c|}{$\begin{array}{l}\text { Pregnancy Induced } \\
\text { Hypertension }\end{array}$} & \multirow{3}{*}{ Total } & \multirow{3}{*}{$\mathbf{X}^{2}$} & \multirow{3}{*}{ P Value } \\
\hline & Yes & No & & & \\
\hline & $n(\%)$ & $n(\%)$ & & & \\
\hline \multicolumn{4}{|l|}{ Age group } & \multirow{5}{*}{12.48} & \multirow{5}{*}{0.006} \\
\hline $17-23$ & $0(0)$ & $66(33)$ & $66(33)$ & & \\
\hline $24-30$ & $15(7.5)$ & $98(49)$ & $113(56.5)$ & & \\
\hline $31-37$ & $0(0)$ & $8(4)$ & $8(4)$ & & \\
\hline $38-43$ & $0(0)$ & $13(6.5)$ & $13(6.5)$ & & \\
\hline
\end{tabular}

Table 6: Association between pregnancy induced hypertension and education.

\begin{tabular}{|c|c|c|c|c|c|}
\hline \multirow{3}{*}{ Variables } & \multicolumn{2}{|c|}{$\begin{array}{l}\text { Pregnancy Induced } \\
\text { Hypertension }\end{array}$} & \multirow{3}{*}{ Total } & \multirow{3}{*}{$\mathbf{X}^{2}$} & \multirow{3}{*}{ P Value } \\
\hline & Yes & No & & & \\
\hline & $n(\%)$ & $n(\%)$ & & & \\
\hline \multicolumn{4}{|l|}{ Education } & \multirow{7}{*}{23.43} & \multirow{7}{*}{0.0001} \\
\hline Illiterate & $0(0)$ & $5(2.5)$ & $5(2.5)$ & & \\
\hline Primary & $0(0)$ & $5(2.5)$ & $5(2.5)$ & & \\
\hline SSC & $2(1)$ & $112(56)$ & $114(57)$ & & \\
\hline HSC & $0(0)$ & $12(6)$ & $12(6)$ & & \\
\hline Graduate & $5(2.5)$ & $25(12.5)$ & $30(15)$ & & \\
\hline Postgraduate & $8(4)$ & $26(13)$ & $34(17)$ & & \\
\hline
\end{tabular}

Table 7: Association between pregnancies induced hypertension and occupation.

\begin{tabular}{|c|c|c|c|c|c|}
\hline \multirow{2}{*}{ Variables } & \multicolumn{2}{|c|}{$\begin{array}{c}\text { Pregnancy Induced } \\
\text { Hypertension }\end{array}$} & \multirow{2}{*}{ Total } & \multirow{2}{*}{$\chi^{2}$} & \multirow{2}{*}{ P Value } \\
\cline { 2 - 4 } & Yes & No & & \\
\cline { 2 - 4 } & $\mathbf{N}(\%)$ & $\mathbf{N}(\%)$ & & & \multirow{2}{*}{7.69} \\
\cline { 2 - 4 } Occupation & & & \multirow{2}{*}{0.021} \\
\hline Housewife & $10(5)$ & $155(77.5)$ & $165(82.5)$ & \\
\hline Student & $4(2)$ & $12(6)$ & $16(8)$ & & \\
\hline Service & $1(0.5)$ & $18(9)$ & $19(9.5)$ & & \\
\hline
\end{tabular}

Statistical significant association was found between pregnancy induced hypertension and occupation $(p=0.021<0.05)$.

\section{Discussion}

Pregnancy induced hypertension is thought to be one of the major causes of maternal death and sufferings all over the country. This study was conducted to know prevalence of pregnancy induced hypertension in third trimester in a teaching hospital. The prevalence of the hypertensive disorders in pregnancy was $7.5 \%$ in this study but $21.6 \%$ and $17.2 \%$ that had been reported from south-eastern Nigeria and Finland, respectively $[16,17]$. However, it was greater than $10 \%$ and $11.6 \%$ that had been reported from Ibadan and Benin City [18,19]. The factor that may be responsible for the low prevalence of hypertensive disorder in our hospital could be due to time constraint and small sample size. In this study, history of preeclampsia was $2 \%$. This disagrees with the $5-10 \%$ prevalence of other studies carried out in Lagos, Ibadan, Calabar, Kano and other parts of the world [20-24]. The age and parity distribution of the cases in this study were also similar to those in other reports $[25,26]$. A positive family history of hypertension was found to be a significant risk factor for developing HDP in this study. Women whose mothers suffered from PIH were three times more likely to develop PIH than other women $[27,28]$. Three-fourth of the respondents had family history of hypertension whereas one-fourth had no family history of hypertension. Multiple pregnancy, gestational diabetes and previous history of preeclampsia were significant risk factors for developing HDP. This findings were same as in other studies $[29,30]$. These are consistent with the hypothesis that immune maladaptation might play a role in triggering the development of HDP. Almost 98\% respondents had no previous history of pregnancy induced hypertension whereas $2 \%$ had previous history of pregnancy induced hypertension. Most of the respondents (96\%) did not have history of gestational diabetes. It was also found that BMI $>27 \mathrm{~kg} / \mathrm{m} 2$ was associated significantly with the risk of the development of HDP. It has been observed that obese women were more likely to have increased levels of serum triglycerides, very low-density lipoproteins and formation of small, dense low-density lipoprotein particles. Such lipid alterations have been suggested to promote oxidative stress, caused by either ischaemia-reperfusion mechanism or activated neutrophils and lead to endothelial cell dysfunction [31]. More than half of the respondents (64\%) suffered from moderate anemia followed by mild anemia $32 \%$ and severe anemia $4 \%$. Underweight, normal, overweight and obese were 4\%, 28.50\%, $26.50 \%$ and $41 \%$. Statistical significant association was found between pregnancy induced hypertension and socioeconomic status. A prospective study conducted by Bener and Saleh revealed that obesity increased the odds of developing PIH by 10 times [32]. Obesity among women in Zimbabwe has increased from $1.2 \%$ in 2005 to $15.1 \%$ in 2010 [33,34]. Other studies have also shown that obesity is a risk factor for PIH $[35,36]$ hence if such women were to become pregnant, they would be at higher risk of developing PIH. Compared to the recommendations by the World Health Organization (WHO), the caesarean section delivery rate of $12.5 \%$ is above the recommended cut off. WHO recommends caesarean section rates between $5 \%$ and $10 \%$ and rates of $15 \%$ are considered to do more harm than good. Literature suggests that cesarean section rates higher than the proposed 15\% upper threshold are associated with increased morbidity and mortality for both mothers and babies [37]. A population-based retrospective cohort study conducted in Zhejiang province in China in 1995-2000 demonstrates the importance of use of cesarean section during delivery among women with PIH. It was found that moderate and severe PIH early developed during pregnancy could increase the risk of perinatal mortality while the cesarean delivery could decrease the risks in women with PIH [38]. In our study, however, it was 
not noted that among the reasons for caesarean section. Possible selection bias among women recruited into this study cannot be ruled out. The study was conducted over a short period of time thus we could have missed essential characteristics among women who did not get the chance to be part of this study.

\section{Conclusion}

The prevalence of pregnancy induced hypertension was $7.5 \%$. Average age of the respondent's $26.03 \pm 5.77$ years. More than half of the respondents completed SSC level education. Average income of the respondent's was 33100.00 76135.29 BDT. Three-fourth of the respondents had family history of hypertension. More than half of the respondents (64\%) suffered from moderate anemia. Average ANC visit was 4.43 \pm 1.58 . Statistical significant association was found between pregnancy induced hypertension and age group, education and occupation.

\section{References}

1. Chaim SRP, Oliveira SMJV, Kimura AF (2008) Pregnancy-induced hypertension and the neonatal outcome. Acta Paul Enferm 21(1): 5358.

2. (2013) American College of Obstetricians and Gynecologists, Task Force on Hypertension in Pregnancy. Hypertension in pregnancy. Report of the American College of Obstetricians and Gynecologists Task Force on Hypertension in Pregnancy. Obstet Gynecol 122:1122

3. Sibai BM (2003) Diagnosis and management of gestational hypertension and preeclampsia. Obstet Gynecol 102(1): 181-192.

4. Hauth JC, Ewell MG, Levine RJ, EsterlitzJR, Sibai B, et al.(2000) Pregnancy outcomes in healthy nulliparas who developed hypertension. Calcium for Preeclampsia Prevention Study Group. Obstet Gynecol 95(1): 2428.

5. Buchbinder A, Sibai BM, Caritis S, Macpherson C, Hauth J, et al (2002) Adverse perinatal outcomes are significantly higher in severe gestational hypertension than in mild preeclampsia. Am J Obstet Gynecol 186(1): 66-71.

6. Chen XK, Wen SW, Smith G, Yang Q Walker M (2006) Pregnancyinduced hypertension is associated with lower infant mortality in preterm singletons. BJOG 113(5): 544-551.

7. Brown MA, Hague WM, Higgins J, Lowe S, McCowan L, et al. (2000) The detection, investigation and management of hypertension in pregnancy: full consensus statement. Aust N Z J Obstet Gynaecol 40(2): 139-155.

8. (2000) Secretaria de Assistência à Saúde. Gestação de alto risco. (4 $4^{\text {th }}$ edn), Divisão Nacional de Saúde Materno-Infantil, Ministério da Saúde, Brasil.

9. (2004) Why mothers die 2000-2002. The sixth report of the confidential enquiries into maternal deaths in the United Kingdom. RCOG Press, London, UK.

10. Roberts JM, Pearson GD, Cutler JA, Lindheimer MD (2003) Summary of the NHLBI Working Group on Research on Hypertension During Pregnancy. Hypertens 41: 437-445.

11. Barreto S (2003) Factores de riesgo y resultadosperinatalesen la preeclampsia severa: um estudiocaso control. Rev Hosp Matern Infant Ramon Sard 22: 116-120.

12. Ferrazzani S, Luciano R, Garofalo S, D’Andrea V, De Carolis S (2011) Neonatal outcome in hypertensive disorders of pregnancy. Early Hum Dev 87(6): 445-449.

13. Liu CM, Cheng PJ, Chang SD (2008) Maternal Complications and
Perinatal Outcomes Associated with Gestational Hypertension and Severe Preeclampsia in Taiwanese Women. J Formos Med Assoc 107(2): 129-138.

14. Vasheqani F, Atarod Z (2006) A comparison between Plasma lipids concentration in preeclamptic and normotensive women. J Mazandaran Univ Med Sci 16(53): 92-96.

15. Mbah AK, Kornosky JL, Kristensen S, August EM, Alio AP, et al. (2010) Super-obesity and risk for early and late pre-eclampsia. BJOG 117: $997-$ 1004.

16. (2003) National study on essential obstetric care facilities in Nigeria. Federal Ministry of Health, Abuja, Nigeria p. 37.

17. Hartikainen AL, Riita HA, Paula TR (1998) A cohort study of epidemiological associations and outcomes of pregnancies with hypertensive disorders. Hypertens Pregnancy 17(1): 31-41.

18. Salako BL, Aimakhu CO, Odukogbe AA, Olayemi O, Adedapo KS (2004) A review of hypertensive disorders of pregnancy. Afr J Med Med Sci 33(2): 99-103.

19. Ebeigbe PN, Iberase GO, Aziken ME (2007) Hypertensive disorder in pregnancy: Experience with 442 recent consecutive cases in Benin City, Nigeria. Niger Med J 48(4): 94-98.

20. Emuveyan E (1995) Pregnancy induced hypertension. Trop J Obstet Gynaecol 12: 8-11.

21. Itam IH, Ekabule JE (2002) A review of pregnancy outcome in women with eclampsia at the University of Calabar Teaching Hospital, Calabar. Trop J Obstet Gynaecol 18(2): 66-68.

22. Myers JE, Baxer PN (2002) Hypertension diseases and eclampsia. Curr Opin Obstet Gynecol 14(2): 119-125.

23. Audu LR, Ekele BA (2002) A ten-year review of maternal mortality in Sokoto, northern Nigeria. West Afr J Med 21(1): 74-76.

24. Omole-Ohonsi A, Shehu I (2001) Value of antenatal care in the management of pre-eclampsia/eclampsia-light of healing. J Islam Med Assoc 1: 36

25. Hayman R (2003) Hypertension in pregnancy. Obstet Gynaecol 14: $1-10$.

26. Olusanya BO, Solanke OA (2012) Perinatal outcomes associated maternal hypertensive disorders of pregnancy in a developing country. Hypertens Pregnancy 31(1):120-130.

27. Laresgoiti-Servitje E, Gomez-Lopez N, Olson DM (2010) An immunological insight into the origins of pre-eclampsia. Hum Reprod Update 16(5): 510-524.

28. Skjaerven R, Vatten LJ, Wilcox AJ, Rønning T, Irgens LM, et al. (2005) Recurrence of preeclampsia across generations: Exploring foetal and maternal genetic components in a population based cohort. BMJ 331: 877.

29. Odum CU (1995) Multiple pregnancy. Trop J Obstet Gynaecol 12: 12-18.

30. Obed SA, Aniteye P (2007) Pregnancy following eclampsia: A longitudinal study at korle- bu teaching hospital. Ghana Med J 41(3): 139-143.

31. Zusterzeel PL, te Morsche R, Raijmakers MTM, Roes EM, Peters WH, et al. (2002) Paternal contribution to the risk for pre-eclampsia. J Med Genet 39(1): 44-45.

32. Bener A, Saleh NM (2013) The impact of socioeconomic, lifestyle habits and obesity in developing of pregnancy induced hypertension in fast growing country: Global comparisons. Clin Exp Obstet Gynaecol 40(1): 52-57.

33. Ministry of Health \& Child Welfare (2005) National Survey Zimbabwe Non-Communicable Disease Risk Factors - (ZiNCoDs) Preliminary Report. Harare, Zimbabwe, East Africa, pp. 65-66. 
34. (2012) Zimbabwe National Statistics Agency (ZIMSTAT) and ICF International. Zimbabwe Demographic and Health Survey 2010-11. Calverton, ZIMSTAT and ICF International Inc.; 2012, Maryland, USA.

35. Robinson HE, O’Connell CM, Joseph KS, McLeod NL (2005) Outcomes in Pregnancies Complicated by Obesity. Obstet Gynecol 106: 1357-1364.

36. Shabnam S, Humaira N (2010) Pregnancy with Obesity -A Risk Factor for PIH. 9: 3.
37. Chu K, Cortier H, Maldonado F, Mashant T, Ford N, et al. (2012) Cesarean Section Rates and Indications in Sub- Saharan Africa: A Multi-Country Study from Medec ins sans Frontieres. PLoS ONE 7(9): e44484.

38. Ye RW, Liu YH, Ma R, Ren AG, Liu JM (2009) Association between pregnancy-induced hypertension, cesarean delivery and perinatal mortality: a prospective study. Zhonghua Liu Xing Bing Xue Za Zhi 30(9): 891-894.

\begin{tabular}{l} 
Your next submission with Juniper Publishers \\
will reach you the below assets \\
- Quality Editorial service \\
- Swift Peer Review \\
- Reprints availability \\
- E-prints Service \\
- Manuscript Podcast for convenient understanding \\
- Global attainment for your research \\
- Manuscript accessibility in different formats \\
( Pdf, E-pub, Full Text, Audio) \\
- Unceasing customer service \\
Track the below URL for one-step submission \\
https://juniperpublishers.com/online-submission.php \\
\hline
\end{tabular}

